\title{
Oestrogen receptor knockout mice: roles for oestrogen receptors $\alpha$ and $\beta$ in reproductive tissues
}

\author{
Sylvia Curtis Hewitt and Kenneth S. Korach \\ Receptor Biology, Laboratory of Reproductive and Developmental Toxicology, National Institute \\ of Environmental Health Sciences, National Institutes of Health, PO Box 12233, \\ Research Triangle Park, NC 27709, USA
}

\begin{abstract}
Oestrogen is an essential component of female reproduction, with well-characterized functions in the uterus, ovaries, mammary gland and hypothalamic-pituitary axis. The mechanism of oestrogen action involves mediation of the rate of transcription by nuclearlocalized oestrogen receptor molecules. Two oestrogen receptors are present in mouse tissues, oestrogen receptors $\alpha$ and $\beta$. Each receptor exhibits differential tissue expression patterns. Mouse models with genetically engineered disruption or 'knockout' of the oestrogen receptors have been developed. Characterization of the resulting defects in reproductive tissues as well as alterations in physiological and genomic responses has given insight into the receptor-mediated effects of oestrogen in reproduction. Oestrogen receptor $\alpha$ knockout females are infertile because they are anovulatory, have disruption in $\mathrm{LH}$ regulation and have uteri that are insensitive to oestrogen. In contrast, oestrogen receptor $\beta$ knockout females are sub-fertile and primarily lack efficient ovulatory function. Mice with deletion of both oestrogen receptors $\alpha$ and $\beta$ are similar to those lacking oestrogen receptor $\alpha$ only, but exhibit a unique ovarian pathology. These observed phenotypes elucidate the relative roles of the oestrogen receptors in reproductive functions of female rodents.
\end{abstract}

Oestrogens are important modulators of normal mammalian reproductive functions. Biochemical, physiological and genetic studies have elucidated a basic mechanism responsible for responses to oestrogens. Circulating oestrogens enter cells containing specific oestrogen receptor (ER) molecules (Fig. 1). In the absence of serum oestrogen, the ER associates with 'co-repressor' molecules, which inhibit the transcriptional activity of the ER. Binding to oestrogen causes a conformational change in the ER molecule leading to dissociation of co-repressors and allowing recruitment of 'co-activators' (McKenna et al., 1999; McKenna and O'Malley, 2002). Co-activators are molecules that interact with the ER and increase its transcriptional activity, and therefore result in an increased transcription rate of genes that contain ERbinding enhancer DNA sequences (EREs) (Klinge, 2001).

ERs are members of the nuclear receptor (NR) family of transcriptional modulators. NRs modulate transcription by interacting with DNA regulatory sequences that bind discriminately to particular classes of NR as well as with co-activator and co-repressor molecules to regulate the activity of the RNA polymerase complex (Steinmetz et al., 2001; Hermanson et al., 2002; McKenna and O'Malley, 2002). Other examples of NR family members

Email: Curtiss@niehs.nih.gov include additional steroid hormone receptors such as the progesterone and androgen receptors, receptors for vitamins or metabolites such as the vitamin D or retinoic acid receptors, or receptors with no apparent ligand, termed 'orphan' receptors.

In the case of the ER, two receptor molecules have been identified. ER $\alpha$ is found in all reproductive tissues, is the most abundant and hence was the first ER to be identified. ER $\beta$ is the product of a different gene (Kuiper et al., 1996; Tremblay et al., 1997), and bears little similarity to the ER $\alpha$ molecule. However, ER $\alpha$ and ER $\beta$ both bind oestradiol and interact with ERE sequences. Compounds with preferential binding for either $E R \alpha$ or $E R \beta$ have also been synthesized, illustrating that the binding activities of ERs can be distinguished (Katzenellenbogen and Katzenellenbogen, 2000; Katzenellenbogen et al., 2001; Meyers et al., 2001; Mortensen et al., 2001; Shiau et al., 2002). Both receptors are also distinct in their transcriptional activities, with ER $\beta$ showing less potent activity than ER $\alpha$ in most contexts as well as the ability to inhibit ER $\alpha$ activity (Kuiper and Gustafsson, 1997; Paech et al., 1997; Barkhem et al., 1998; Kuiper et al., 1998; Montano et al., 1998; Hall and McDonnell, 1999). ERß expression is most abundant in the mouse in the ovary, uterus, lung, neural tissue as well as male reproductive tissues, although in all of these tissues except the ovary, $E R \alpha$ is more abundantly expressed (Couse et al., 1997). 


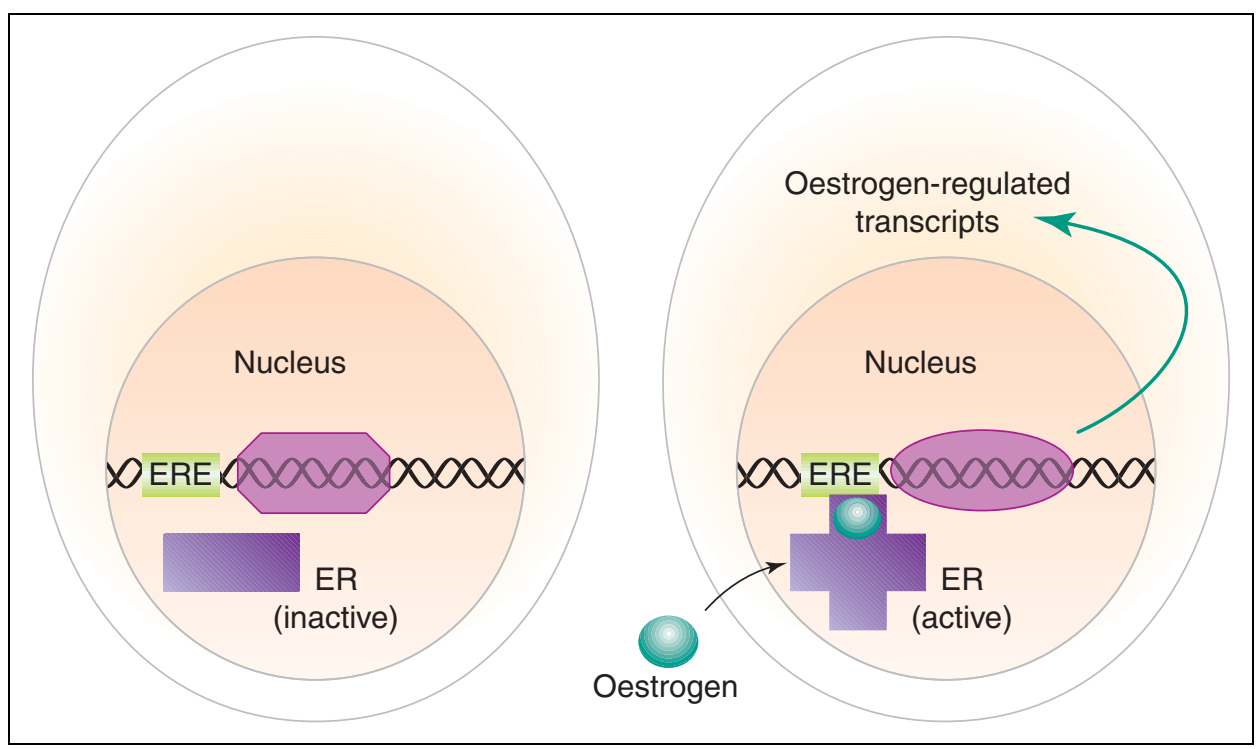

Fig. 1. Simplified illustration of the mechanism of oestrogen action in a target cell. Oestrogen can diffuse from the serum into cells. If the nuclear oestrogen receptor (ER) is present, oestrogen will bind and convert the ER to an active conformation. The conformational change causes the dissociation of transcription repressors and the association of transcription co-activator molecules (not shown). Through interaction with specific oestrogen responsive enhancer (ERE) DNA sequences, the active ER modulates the rate of transcription.

Studies using human samples have shown the presence of ER $\beta$ transcripts in the breast, ovary, testis, uterus, thymus, intestine and kidney (Mosselman et al., 1996; Enmark et al., 1997). In the mouse ovary, ER $\alpha$ is expressed primarily in the thecal and interstitial regions, whereas ER $\beta$ is primarily expressed in the granulosa cells (Schomberg et al., 1999), indicating that although both ERs are present in the ovary, they are not present in the same cells and therefore are unable to interact directly in vivo.

\section{Oestrogen receptor knockout models illustrate roles of ERs in reproduction}

Much of our understanding of the physiological roles of oestrogens has come from studies in which circulating oestrogen is depleted by ovariectomy and replaced with exogenous treatments. However, such approaches do not discriminate between responses modulated by $E R \alpha$, ER $\beta$ or via another mechanism. The advent of gene deletion techniques has allowed the generation of mice lacking $\mathrm{ER} \alpha(\alpha \mathrm{ERKO}$; Lubahn et al., 1993; Couse and Korach, 1999), ER $\beta$ ( $\beta E R K O ;$ Krege et al., 1998) or both ER $\alpha$ and ER $\beta(\alpha \beta E R K O$; Couse et al., 1999a), as well as mice that lack the ability to synthesize oestrogens due to deletion of the aromatase gene (ArKO; Fisher et al., 1998). Characterization of the phenotypes exhibited by these models has extended our understanding of the physiological processes governed by oestrogens.

Initial analysis indicates complete infertility in both male and female $\alpha$ ERKO and $\alpha \beta E R K O$ mice, whereas
BERKO males exhibit normal fertility (Lubahn et al., 1993; Eddy et al., 1996; Krege et al., 1998; Couse and Korach, 1999). $\beta$ ERKO females overall exhibit decreased fertility, with three subsets of phenotypes in a continuous mating study (Dupont et al., 2000). Some $\beta E R K O$ females are completely infertile; a second subset exhibits a decreased rate of pregnancies; and a third subset has a normal number of litters but delivers smaller litters.

The decreased or lost fertility prompted further investigation of the requirements for ERs for normal fertility. In the case of females, successful reproduction requires coordinated functions of the hypothalamic-pituitary axis, the ovary, the uterus and the mammary gland. The functions of these components in the various ER knockout models were analysed and compared (Table 1).

\section{Pituitary functions}

The pituitary gland, in concert with gonadotrophin releasing hormone pulses from the hypothalamus, is responsible for sensing the endocrine environment and releasing gonadotrophins or lactotrophic hormones. The pituitary hormones must be produced and released in a properly regulated manner for successful oocyte development and ovulation to occur. The production of the gonadotrophins $\mathrm{LH}$ and $\mathrm{FSH}$ are regulated by a negative feedback mechanism in which the oestradiol surge that occurs at ovulation acts upon the pituitary to negatively regulate $\mathrm{GnRH}$ secretion, ultimately leading to a decrease in serum gonadotrophins (Gharib et al., 1990) (Fig. 2). Accordingly, LH mRNA and protein are 
Table 1. Components of female reproductive system and phenotypes noted in oestrogen receptor knockout (ERKO) mice

\begin{tabular}{|c|c|c|}
\hline Component & Function & Phenotypes \\
\hline Pituitary gland & $\begin{array}{l}\text { Production and secretion of } \\
\text { gonadotrophins }\end{array}$ & $\begin{array}{l}\alpha \text { ERKO and } \alpha \beta E R K O: \text { high } \mathrm{LH} \\
\beta E R K O: \text { none }\end{array}$ \\
\hline Ovary & $\begin{array}{l}\text { Production of progesterone and oestradiol, } \\
\text { ovulation }\end{array}$ & $\begin{array}{l}\alpha \text { ERKO: haemorrhagic cystic, high oestrogen and } \\
\text { testosterone due to high } \mathrm{LH} \text {, anovulatory } \\
\beta \text { ERKO: reduced ovulations } \\
\alpha \beta \text { ERKO: lack of ovulation, sex-reversed follicles }\end{array}$ \\
\hline Uterus & Proliferation, secretion & $\begin{array}{l}\alpha \text { ERKO and } \alpha \beta E R K O \text { : oestrogen insensitive }- \text { no growth or } \\
\text { induction of oestrogen target genes } \\
\beta E R K O: \text { normal growth and responses to oestrogen }\end{array}$ \\
\hline Embryo/uterus & Implantation/decidualization & $\begin{array}{l}\alpha \text { ERKO: oestrogen independent decidualization, no implantation } \\
\beta E R K O: \text { normal }\end{array}$ \\
\hline Mammary gland & Pubertal development, lactation & $\begin{array}{l}\alpha E R K O, \alpha \beta E R K O: \text { no pubertal development } \\
\beta E R K O: \text { normal development and lactation }\end{array}$ \\
\hline
\end{tabular}

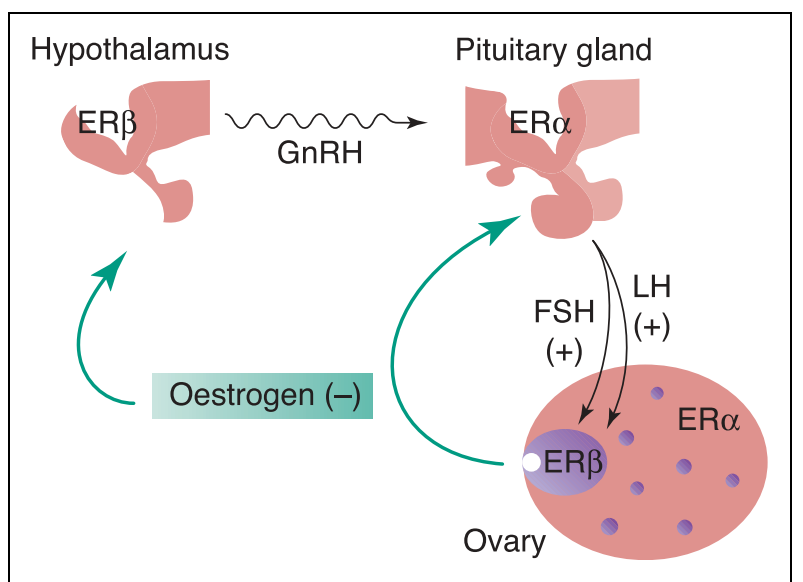

Fig. 2. Regulation of mouse ovary by the hypothalamic-pituitary axis. Pulsatile release of gonadotrophin releasing hormone $(\mathrm{GnRH})$ from the hypothalamus regulates release of the gonadotrophins FSH and LH from the pituitary gland. The gonadotrophins act upon the ovary, resulting in recruitment and maturation of follicles. The maturing follicle causes an increase in serum oestradiol, which downregulates $\mathrm{GnRH}$ release and the synthesis of $\mathrm{LH}$ and $\mathrm{FSH}$. Hypothesized localizations of $\mathrm{ER} \alpha$ and $\beta$ isoforms are indicated.

increased in $\alpha E R K O$ and $\alpha \beta E R K O$ female pituitary gland (mRNA) and serum (protein), indicating that the infertility in these females may in part have resulted from inability to properly regulate pituitary gonadotrophin concentrations (Couse and Korach, 1999). Concentrations of LH and $\mathrm{FSH}$ in the $\beta E R K O$ female appear to be normal, indicating that $\mathrm{ER} \alpha$ is the ER that mediates the negative feedback regulation of $\mathrm{LH}$.

\section{Ovaries}

As the proper expression of pituitary gonadotrophins is necessary to stimulate ovulation successfully, it is not surprising that examination of the $\alpha$ ERKO ovaries reveals lack of fully developed follicles and no apparent corpora lutea. In addition, the ovaries contain many blood-filled cystic structures (Couse and Korach, 1999). This phenotype has also been described in transgenic mice that over-express LH $\beta$ (Risma et al., 1995), indicating that the appearance of the ovaries in the $\alpha$ ERKO is the result of the exposure to increased concentrations of $\mathrm{LH}$. In agreement with this hypothesis, prevention of $\mathrm{LH}$ production in $\alpha$ ERKO mice using GnRH antagonist prevents development of the cystic structures (Couse et al., 1999a). Unlike the $\alpha$ ERKO ovaries, the $\beta E R K O$ ovaries appear to contain normal follicles at all stages of development as well as corpora lutea (Krege et al., 1998).

The ovaries are the primary source of oestradiol and progesterone. As a measure of this aspect of ovarian function, serum hormone concentrations were assayed in the ERKO mice. Concentrations of progesterone in the $\alpha$ ERKO and $\beta E R K O$ mice are similar to the average of wild-type cyclic mice, whereas oestradiol concentration is increased in the $\alpha E R K O$ but normal in the $\beta E R K O$ mouse (Couse and Korach, 1999). $\alpha$ ERKO, $\beta E R K O$ and control wild-type mice were treated with exogenous gonadotrophins using a standard superovulation protocol to determine whether the ovaries could respond to gonadotrophins. When $\alpha$ ERKO females were treated with exogenous gonadotrophins, only $35 \%$ as many ovulations were observed in comparison with control females (Couse et al., 1999b). Similarly, fewer ovulations $(18 \%$ as many as in the controls) occurred in the $\beta E R K O$ females treated with exogenous gonadotrophins (Krege et al., 1998). In agreement with the continuous mating study, distinct differences in responses were seen in the superovulation trial in the $\beta E R K O$ mice. One group did not ovulate, whereas another group could be induced to ovulate but the number of oocytes released was reduced. Examination of the $\alpha$ ERKO and $\beta E R K O$ ovaries after superovulation showed a reduced number of corpora lutea and a number of un-ruptured antral follicles. 
Taken together, these ovarian studies emphasize that the infertility in these ERKO models can be partly accounted for by the inability to induce ovulation. In addition, these observations illustrate that both $E R \alpha$ and $E R \beta$ are required for ovulation to occur efficiently, although some ovulations were induced in their absence.

\section{$\alpha \beta E R K O$ ovaries}

Examination of the ovaries of $\alpha \beta E R K O$ mice indicated a phenotype distinct from those observed in ovaries from $\alpha E R K O$ or $\beta E R K O$ mice (Couse et al., 1999b). Normal follicles, with a developing oocyte surrounded by granulosa cells were apparent, but follicles with an unusual appearance appeared progressively with age. These follicles lacked an oocyte and contained what appeared to be Sertoli cells, which are normally found in the testis. In addition, intermediate structures with characteristics of both types of follicles, containing a degenerating oocyte and both granulosa and Sertoli-like cells, were also present. Thus, follicles that appear normal, begin to 'trans-differentiate' as the oocytes degenerates, into seminiferous tubule-like follicles. Similar structures have also been reported in the ArKO mouse, which is unable to synthesize oestradiol (Britt et al., 2001). Therefore, lack of both $E R \alpha$ and $E R \beta$ or the lack of ligand to activate either ER, results in a unique phenotype unlike that of either of the individual ER knockout models. The mechanism leading to the follicular 'trans-differentiation' is under investigation, but is also similar to structures observed in models that lack germ cells (Behringer et al., 1990; Whitworth, 1998). Thus the combined functions of $E R \alpha$ and $E R \beta$ may be necessary to maintain oocyte integrity and prevent follicular degeneration.

\section{Uterus}

The uterus plays a central role in reproduction. In mice, the uterus responds to the ovarian hormones oestradiol and progesterone in preparation for embryo implantation and to the implanting embryo with a massive differentiation of the stromal cell component. Therefore, the development and functioning of the uteri from $\alpha E R K O, \beta E R K O$ or $\alpha \beta E R K O$ mice were studied as components contributing to infertility. The uteri of both the $\alpha$ ERKO and $\alpha \beta E R K O$ are similarly immature in appearance (Lubahn et al., 1993; Couse et al., 1999b). Thus, although lack of $E R \alpha$ does not prevent normal uterine development, post-pubertal growth is disrupted. In addition, uteri of $\alpha$ ERKO and $\alpha \beta E R K O$ mice do not exhibit sensitivity to oestradiol treatment, as evidenced by: (1) lack of a growth response and (2) lack of induction of target genes, such as lactoferrin and progesterone receptor (Couse et al., 1995). The uteri of $\beta E R K O$ mice appear comparable to that of a wild type, and respond normally to oestrogen treatment. In addition, although the $\beta E R K O$ females exhibit decreased fertility, they are able to carry pregnancies successfully to term, indicating normal uterine function (Krege et al., 1998).

\section{Cross-talk}

Oestrogen induces the expression of membrane receptor tyrosine kinase ligands, epidermal growth factor (EGF) and insulin-like growth factor I (IGF-I) in the mouse uterus. In addition, oestrogen treatment results in activation of the IGF-I receptor signalling pathway (Richards et al., 1996). When IGF-I knockout mice are treated with oestradiol, uterine epithelial cells do not undergo mitosis, indicating that activation of the IGF-I pathway is necessary for this uterine response to oestrogen (Adesanya et al., 1999). Conversely, EGF or IGF-I administered in an exogenous dose can induce oestrogen-like responses, such as epithelial mitogenesis, induction of oestrogen target genes and increase in uterine mass (Nelson et al., 1991; Ignar Trowbridge et al., 1992). The mechanism appears to involve $E R \alpha$, as studies using cells in vitro show a requirement for $E R \alpha$ for IGF-I or EGF to induce oestrogen-responsive reporter constructs (Ignar Trowbridge et al., 1992, 1993). These studies have led to a model of 'cross-talk' in which growth factor receptor activation results in maintenance, amplification or induction of ER transcriptional activity even in the absence of circulating oestrogens. $\alpha E R K O$ mice were treated with IGF-I and EGF to determine whether $E R \alpha$ is required for uterine responses to these growth factors. In both cases, the necessary membrane growth factor receptors were present and activated by the treatment (Curtis et al., 1996; Klotz et al., 2002). In addition, cfos was induced by EGF in the $\alpha E R K O$, indicating that the EGFR signalling pathway was fully functional (Curtis et al., 1996). However, no thymidine or bromodeoxyuridine incorporation was induced, indicating that the EGF and IGF-I did not induce a mitogenic response (Curtis et al., 1996; Klotz et al., 2002), and therefore that this response requires $E R \alpha$. Studies using ovariectomized mice containing an oestrogen-responsive luciferase reporter transgene indicated that IGF-I could induce luciferase activity in the uterus in the absence of oestrogen (Klotz et al., 2002), demonstrating that the IGF-I treatment results in activation of ER transcriptional activity in vivo.

\section{Uterine progesterone responsiveness}

The $\alpha E R K O$ uterine response to oestrogen, including induction of the progesterone receptor gene (PR) was impaired. Therefore, the ability of the $\alpha E R K O$ uterus to respond to progesterone was also studied. Although the PR gene is not induced by oestrogen in the $\alpha$ ERKO uterus, progesterone receptors are detected by western blot analysis as well as radioligand binding (Curtis et al., 1999). The PR is present in the $\alpha E R K O$ uterus at 
about $60 \%$ of that present in ER $\alpha$-containing wild-type controls. Progesterone-responsive genes were induced in the uteri of $\alpha E R K O$ mice, indicating that the PR present was sufficient for normal transcriptional responses (Curtis et al., 1999).

Progesterone is essential in modulating the decidual transformation of the stromal component of the rodent uterus in response to embryo implantation. The decidual transformation of the stromal layer can also be induced with oestrogen and progesterone priming and infusion of oil into the uterine lumen. The ability to elicit a decidual response is commonly used as a measure of progesterone responsiveness. Uterine decidualization was experimentally induced to determine whether the $P R$ in the $\alpha E R K O$ uterus was sufficient to modulate this physiological response. Although this response in mice normally requires oestrogen, decidualization could be induced in the $\alpha E R K O$ uterus (Curtis et al., 1999). Thus, not only is the PR functional for this biological response, the requirement for oestrogen signalling in this response has been relieved.

Although the decidual response is an important component of pregnancy, and was present in the uteri of $\alpha$ ERKO mice, the ability to implant embryos is required to initiate pregnancy. As the $\alpha E R K O$ is anovulatory, the ability of the uterus to implant embryos was studied through experimental transfer of donor embryos into a hormone-primed $\alpha$ ERKO uterus. Although implantations were seen after embryo transfer into hormone-primed control mice, no donor embryo implantations were seen in identically treated $\alpha E R K O s$, indicating that implantation requires $\mathrm{ER} \alpha$.

Lack of decidual response has been reported in several mouse knockout models. These include mice with disruption in the PR (Lydon et al., 1995), prostaglandin synthetase 2 or Cox2 (an enzyme that synthesizes prostaglandin precursors; Lim et al., 1997), Hoxa10 (a homeobox protein expressed in the developing reproductive tract; Ma et al., 1998), leukaemia inhibitory factor (LIF, an oestrogen-inducible cytokine; Chen et al., 2000) and interleukin 11 receptor (IL-11, a cytokine receptor; Robb et al., 1998). Thus, these genes are all important for a decidual response. In an attempt to determine the mechanism that allows decidualization to occur in the uteri of $\alpha$ ERKO mice without oestrogen priming, the expression of these genes known to be required for decidual response as well as responses induced by intraluminal oil infusion were investigated. These studies indicate the following points. (1) PR, as mentioned above, was expressed in the $\alpha$ ERKO uterus. The hormonal and oil infusion treatments did not result in any differences in PR expression in samples prepared from whole uteri of $\alpha$ ERKO mice as compared with wildtype controls. However, the oil infusion did result in increased PR immunohistological staining in the stroma that was enhanced by oestrogen priming in the wild type, but did not require oestrogen priming in the $\alpha E R K O$, indicating that the $\alpha E R K O$ stroma might exhibit increased progesterone sensitivity without oestrogen priming. In addition, the $\alpha E R K O$ tissue exhibited tissue damage, indicating that the oil infusion was more 'traumatic' in the $\alpha \mathrm{ERKO}$ than in the wild type (Hewitt et al., 2002). Trauma to the mouse uterus has been reported to allow decidualization to develop in the absence of oestrogen priming (Finn, 1965, 1966). (2) Hoxa10 is expressed identically in wild-type and $\alpha$ ERKO samples (Hewitt et al., 2002). (3) Cox2 expression is rapidly and robustly induced after oil infusion in both wild-type and $\alpha$ ERKO samples. This expression is maintained $24 \mathrm{~h}$ after oil infusion, but in the wild type this maintained expression requires oestrogen priming, whereas in the $\alpha$ ERKO the expression is maintained independent of oestrogen (Hewitt et al., 2002). (4) Although LIF is not induced in the $\alpha E R K O$ in response to oestrogen, it is rapidly and robustly induced in wild-type and $\alpha$ ERKO samples after oil infusion. This induction is more robust in the $\alpha$ ERKO samples, which might allow the $\alpha$ ERKO to compensate for the lack of oestrogen induction. (5) Stat3, a transcription factor activated in response to cytokine receptor signalling, is activated rapidly after oil infusion (Hewitt et al., 2002). This indicates that the signalling induced by the oil infusion might involve LIF or other cytokines.

\section{Mammary glands}

The phenotype present in the mammary glands of the $\alpha E R K O$ illustrates the role of ER $\alpha$ in mammary gland development. At birth, the mouse mammary gland consists of a rudimentary ductal tree that develops and fills the stroma of the gland in response to increased ovarian steroids at puberty. The $\alpha$ ERKO mammary glands do not grow beyond the rudimentary duct, illustrating the role of oestrogen in ductal elongation (Couse and Korach, 1999). As the $\alpha E R K O$ females do not ovulate, endogenous progesterone concentrations are insufficient to support lobular alveolar development. The rudimentary structure can be induced to develop lobular alveolar structures with progesterone treatment, indicating that the progesterone responsiveness of the mammary ducts is maintained in the $\alpha$ ERKO (Hewitt and Korach, 2000). The $\beta E R K O$ mammary gland develops normally, and as $\beta E R K O$ mothers are able to nurse their young, they function normally, indicating a lack of requirement for $E R \beta$ in mammary gland function (Couse and Korach, 1999).

\section{Conclusion}

The phenotypes that result from the deletion of ERs have allowed study of the relative roles of the different ERs in female fertility. In most cases, ER $\alpha$ is the receptor necessary to modulate normal function. However, ER $\beta$ ablation adversely affects ovarian function. Further 
studies will help illustrate the molecular and genomic components involved in the functions of reproductive tissues requiring oestrogen.

\section{References}

Key references are identified by asterisks.

Adesanya OO, Zhou J, Samathanam C, Powell-Braxton L and Bondy CA (1999) Insulin-like growth factor 1 is required for G2 progression in the estradiol-induced mitotic cycle Proceedings National Academy of Sciences USA 96 3287-3291

Barkhem T, Carlsson B, Nilsson Y, Enmark E, Gustafsson J and Nilsson S (1998) Differential response of estrogen receptor alpha and estrogen receptor beta to partial estrogen agonists/antagonists Molecular Pharmacology 54 105-112

Behringer RR, Cate RL, Froelick GJ, Palmiter RD and Brinster RL (1990) Abnormal sexual development in transgenic mice chronically expressing mullerian inhibiting substance Nature 345 167-170

Britt KL, Drummond AE, Dyson M, Wreford NG, Jones MEE, Simpson ER and Findlay JK (2001) The ovarian phenotype of the aromatase knockout (ArKO) mouse Journal of Steroid Biochemistry and Molecular Biology 79 181-185

Chen JR, Cheng JG, Shatzer T, Sewell L, Hernandez L and Stewart CL (2000) Leukemia inhibitory factor can substitute for nidatory estrogen and is essential to inducing a receptive uterus for implantation but is not essential for subsequent embryogenesis Endocrinology 141 4365-4372

* Couse JF and Korach KS (1999) Estrogen receptor null mice: what have we learned and where will they lead us? Endocrine Reviews 20 358-417

Couse JF, Curtis SW, Washburn TF, Lindzey J, Golding TS, Lubahn DB, Smithies O and Korach KS (1995) Analysis of transcription and estrogen insensitivity in the female mouse after targeted disruption of the estrogen receptor gene Molecular Endocrinology 9 1441-1454

Couse JF, Lindzey J, Grandien K, Gustafsson JA and Korach KS (1997) Tissue distribution and quantitative analysis of estrogen receptor-alpha (ERalpha) and estrogen receptor-beta (ERbeta) messenger ribonucleic acid in the wild-type and ERalpha-knockout mouse Endocrinology 138 4613-4621

Couse JF, Hewitt SC, Bunch DO, Sar M, Walker VR, Davis BJ and Korach KS (1999a) Postnatal sex reversal of the ovaries in mice lacking estrogen receptors alpha and beta Science 286 2328-2331

Couse JF, Bunch DO, Lindzey J, Schomberg DW and Korach KS (1999b) Prevention of the polycystic ovarian phenotype and characterization of ovulatory capacity in the estrogen receptor-alpha knockout mouse Endocrinology 140 5855-5865

Curtis SW, Washburn T, Sewall C, DiAugustine R, Lindzey J, Couse JF and Korach KS (1996) Physiological coupling of growth factor and steroid receptor signaling pathways: estrogen receptor knockout mice lack estrogen-like response to epidermal growth factor Proceedings National Academy of Sciences USA 9312 626-12 630

Curtis SW, Clark J, Myers P and Korach KS (1999) Disruption of estrogen signaling does not prevent progesterone action in the estrogen receptor or knockout mouse uterus Proceedings National Academy of Sciences USA 96 3646-3651

Dupont S, Krust A, Gansmuller A, Dierich A, Chambon P and Mark M (2000) Effect of single and compound knockouts of estrogen receptors alpha (ERalpha) and beta (ERbeta) on mouse reproductive phenotypes Development 127 4277-4291

Eddy EM, Washburn TF, Bunch DO, Goulding EH, Gladen BC, Lubahn DB and Korach KS (1996) Targeted disruption of the estrogen receptor gene in male mice causes alteration of spermatogenesis and infertility Endocrinology 137 4796-4805

Enmark E, Pelto-Huikko M, Grandien K, Lagercrantz S, Lagercrantz J, Fried G, Nordenskjold M and Gustafsson JA (1997) Human estrogen receptor beta-gene structure, chromosomal localization, and expression pattern Journal of Clinical Endocrinology and Metabolism $824258-4265$

Finn CA (1965) Oestrogen and the decidual cell reaction of implantation in mice Journal of Endocrinology 32 223-229
Finn CA (1966) Endocrine control of endometrial sensitivity during the induction of the decidual cell reaction in the mouse Journal of Endocrinology 36 239-248

* Fisher CR, Graves KH, Parlow AF and Simpson ER (1998) Characterization of mice deficient in aromatase (ArKO) because of targeted disruption of the cyp19 gene Proceedings National Academy of Sciences USA 95 6965-6970

Gharib SD, Wierman ME, Shupnik MA and Chin WW (1990) Molecular biology of the pituitary gonadotropins Endocrine Reviews 11177 199

Hall JM and McDonnell DP (1999) The estrogen receptor beta-isoform (ER beta) of the human estrogen receptor modulates ER alpha transcriptional activity and is a key regulator of the cellular response to estrogens and antiestrogens Endocrinology 140 5566-5578

Hermanson O, Glass CK and Rosenfeld MG (2002) Nuclear receptor coregulators: multiple modes of modification Trends in Endocrinology and Metabolism 13 55-60

Hewitt SC and Korach KS (2000) Progesterone action and responses in the alpha ERKO mouse Steroids 65 551-557

Hewitt SC, Goulding EH, Eddy EM and Korach KS (2002) Studies using the estrogen receptor alpha knockout uterus demonstrate that implantation but not decidualization-associated signaling is estrogen dependent Biology of Reproduction 67 1268-1277

Ignar Trowbridge DM, Nelson KG, Bidwell MC, Curtis SW, Washburn TF, McLachlan JA and Korach KS (1992) Coupling of dual signaling pathways: epidermal growth factor action involves the estrogen receptor Proceedings National Academy of Sciences USA 89 4658-4662

Ignar Trowbridge DM, Teng CT, Ross KA, Parker MG, Korach KS and McLachlan JA (1993) Peptide growth factors elicit estrogen receptordependent transcriptional activation of an estrogen-responsive element Molecular Endocrinology 7 992-998

Katzenellenbogen BS and Katzenellenbogen JA (2000) Estrogen receptor transcription and transactivation: estrogen receptor alpha and estrogen receptor beta: regulation by selective estrogen receptor modulators and importance in breast cancer Breast Cancer Research 2 335-344

Katzenellenbogen BS, Sun J, Harrington WR, Kraichely DM, Ganessunker D and Katzenellenbogen JA (2001) Structure-function relationships in estrogen receptors and the characterization of novel selective estrogen receptor modulators with unique pharmacological profiles Annals of the New York Academy of Sciences 949 6-15

* Klinge CM (2001) Estrogen receptor interaction with estrogen response elements Nucleic Acids Research 29 2905-2919

Klotz DM, Hewitt SC, Ciana P, Raviscioni M, Lindzey JK, Foley J, Maggi A, DiAugustine RP and Korach KS (2002) Requirement of estrogen receptoralpha in insulin-like growth factor 1 (IGF-1)-induced uterine responses and in vivo evidence for IGF-1/estrogen receptor cross-talk Journal of Biological Chemistry 277 8531-8537

Krege JH, Hodgin JB, Couse JF, Enmark E, Warner M, Mahler JF, Sar M, Korach KS, Gustafsson JA and Smithies O (1998) Generation and reproductive phenotypes of mice lacking estrogen receptor beta Proceedings National Academy of Sciences USA 95 15 677-15 682

Kuiper GG and Gustafsson JA (1997) The novel estrogen receptor-beta subtype: potential role in the cell- and promoter-specific actions of estrogens and anti-estrogens Federation of European Biochemical Societies Letters 410 87-90

*Kuiper GG, Enmark E, Pelto-Huikko M, Nilsson S and Gustafsson JA (1996) Cloning of a novel receptor expressed in rat prostate and ovary Proceedings National Academy of Sciences USA 93 5925-5930

Kuiper G, Shughrue PJ, Merchenthaler I and Gustafsson JA (1998) The estrogen receptor beta subtype: a novel mediator of estrogen action in neuroendocrine systems Frontiers in Neuroendocrinology 19253 286

Lim H, Paria BC, Das SK, Dinchuk JE, Langenbach R, Trzaskos JM and Dey SK (1997) Multiple reproductive failures in cyclooxygenase 2-deficient mice Cell 91 197-208

Lubahn DB, Moyer JS, Golding TS, Couse JF, Korach KS and Smithies O (1993) Alteration of reproductive function but not prenatal sexual development after insertional disruption of the mouse estrogen receptor gene Proceedings National Academy of Sciences USA 90 11 162-11 166 
Lydon JP, DeMayo FJ, Funk CR, Mani SK, Hughes AR, Montgomery CA, Shyamala G, Conneely OM and O'Malley BW (1995) Mice lacking progesterone receptor exhibit pleiotropic reproductive abnormalities Genes and Development 9 2266-2278

Ma L, Benson GV, Lim H, Dey SK and Maas RL (1998) Abdominal B (AbdB) Hoxa genes: regulation in adult uterus by estrogen and progesterone and repression in mullerian duct by the synthetic estrogen diethylstilbestrol (DES) Developmental Biology 197 141-154

McKenna NJ and O'Malley BW (2002) Combinatorial control of gene expression by nuclear receptors and coregulators Cell 108 465-474

* McKenna NJ, Lanz RB and O'Malley BW (1999) Nuclear receptor coregulators: cellular and molecular biology Endocrine Reviews 20321 344

Meyers MJ, Sun J, Carlson KE, Marriner GA, Katzenellenbogen BS and Katzenellenbogen JA (2001) Estrogen receptor-beta potency-selective ligands: structure-activity relationship studies of diarylpropionitriles and their acetylene and polar analogues Journal of Medicinal Chemistry $\mathbf{4 4}$ 4230-4251

Montano MM, Jaiswal AK and Katzenellenbogen BS (1998) Transcriptional regulation of the human quinone reductase gene by antiestrogenliganded estrogen receptor-alpha and estrogen receptor-beta Journal of Biological Chemistry 27325 443-25 449

Mortensen DS, Rodriguez AL, Carlson KE, Sun J, Katzenellenbogen BS and Katzenellenbogen JA (2001) Synthesis and biological evaluation of a novel series of furans: ligands selective for estrogen receptor alpha Journal of Medicinal Chemistry 44 3838-3848

Mosselman S, Polman J and Dijkema R (1996) ER beta: identification and characterization of a novel human estrogen receptor Federation of European Biochemical Societies Letters 392 49-53

Nelson KG, Takahashi T, Bossert NL, Walmer DK and McLachlan JA (1991) Epidermal growth factor replaces estrogen in the stimulation of female genital-tract growth and differentiation Proceedings National Academy of Sciences USA 88 21-25
Paech K, Webb P, Kuiper GG, Nilsson S, Gustafsson J, Kushner PJ and Scanlan TS (1997) Differential ligand activation of estrogen receptors ERalpha and ERbeta at AP1 sites Science 277 1508-1510

Richards RG, DiAugustine RP, Petrusz P, Clark GC and Sebastian J (1996) Estradiol stimulates tyrosine phosphorylation of the insulin-like growth factor- 1 receptor and insulin receptor substrate- 1 in the uterus Proceedings National Academy of Sciences USA 93 12 002-12 007

Risma KA, Clay CM, Nett TM, Wagner T, Yun J and Nilson JH (1995) Targeted overexpression of luteinizing hormone in transgenic mice leads to infertility, polycystic ovaries, and ovarian tumors Proceedings National Academy of Sciences USA 92 1322-1326

Robb L, Li R, Hartley L, Nandurkar HH, Koentgen F and Begley CG (1998) Infertility in female mice lacking the receptor for interleukin 11 is due to a defective uterine response to implantation Nature Medicine $\mathbf{4}$ 303-308

Schomberg DW, Couse JF, Mukherjee A, Lubahn DB, Sar M, Mayo KE and Korach KS (1999) Targeted disruption of the estrogen receptoralpha gene in female mice: characterization of ovarian responses and phenotype in the adult Endocrinology 140 2733-2744

Shiau AK, Barstad D, Radek JT, Meyers MJ, Nettles KW, Katzenellenbogen BS, Katzenellenbogen JA, Agard DA and Greene GL (2002) Structural characterization of a subtype-selective ligand reveals a novel mode of estrogen receptor antagonism Nature Structural Biology 9 359364

Steinmetz ACU, Renaud JP and Moras D (2001) Binding of ligands and activation of transcription by nuclear receptors Annual Review of Biophysics and Biomolecular Structure 30 329-359

*Tremblay GB, Tremblay A, Copeland NG, Gilbert DJ, Jenkins NA, Labrie F and Giguere V (1997) Cloning, chromosomal localization, and functional analysis of the murine estrogen receptor beta Molecular Endocrinology 11 353-365

Whitworth DJ (1998) XX germ cells: the difference between an ovary and a testis Trends in Endocrinolgy and Metabolism 9 2-6 